\title{
The humane management of Ideological and Political Education of College Students
}

\author{
Liying Zhang ${ }^{1, \text { a }}$ \\ ${ }^{1}$ Law College, Beihua University, Jilin 132013, China. \\ aliying_zhang@126.com
}

Keywords: ideological and political education, human rights and humane, college students.

\begin{abstract}
Under strategy of international human rights and humane environment, the unity of rights and duties, of duties and responsibilities inevitably mean the college students' free activities and the taking of responsibilities would been respected. the college student's ideological and political education should turn from people's tool value to the value of free and full development. In this paper, the effective methods of combining theory and practice is used for guiding college students' taking of responsibilities lies in completing the emphasizing humanity's' theoretical education and of responsibility education.
\end{abstract}

\section{Introduction}

Ideological and political education is an important aspect of human social practice, for the development of man and society has played an irreplaceable role. Ideological and political education in itself with the development of history and the era of the emergence of new theoretical and practical content in its content, form and so on.

CPC Central Committee "Opinions on Strengthening and improving ideological and political work," pointed out: "must adhere to a combination of education and management to establish and improve relevant laws and regulations, strengthen the management of all aspects of social life in accordance with the law, our advocacy. Ideological and moral principles and into the scientific and effective social management in order that discipline and law, internal constraints and external constraints organically combined. " This argument for ideological and political education in the new raises an important issue, namely, how the ideological and political education of college students organically combine management; also pointed out that a combination of direction, that is, the ideological and political education in financial management among . In this regard, the ideological and political education has made some useful exploration.

SOUTH - Zhangyao Can the "principle of ideological and political education," pointed out: "the ideological and political education refers to community or social group with certain ideas, political views, ethics applied to its members purposeful, planned, organized influence, so that they form in line with a certain moral society, it required a certain class of social practice. " The so-called ideological and political education, the colleges and universities according to the party's education policy, purposeful, planned, organized for college students world outlook and methodology of education and exert a certain psychological impact, so that students have a good ideological and political awareness, moral and psychological quality, ideological and political education is to train college students and reflect the objective world of ideas and the ideological and political education of cognitive ability. The object of ideological and political education of the people, for the people mainly produced in the mouth with a lot of everyday life and universal instant awareness of the problem of political issues and value judgments awareness education, moral formation of people meet the requirements of social development, Further pushing society forward.

Ideological and political education management is an important activity of ideological and political education. On "ideological and political education management" is defined, in theory at present there is no more authoritative and unified view. Qin "ideological and political education management theory" that in the East, there are two kinds of current academic define, one by definition to define the rules for management of ideological and political education management, as 
the leader, "the ideological and political education management refers to the ideological and political education institutions and managers, through the ideological and political education for scientific decision-making, planning, organization, control and evaluation, in order to achieve the goal of ideological and political education and ideological and political education to enhance the effectiveness of the system in the process. " The other is by definition rule Leadership to define the ideological and political education management, saying that "the ideological and political education management refers to the management mechanism of ideological and political education, ideological and political education by managers of scientific decision-making and correct command, in order to achieve the ideological and political leadership behavior educational goals of science.

\section{Ideological and Political Education of College Students humane significance}

With the gradual improvement of China's socialist market economic system reform and opening up continue to develop in depth, as well as information technology, the impact of globalization, people's traditional ideology, morality, values and thinking patterns have undergone complex and profound The change. The traditional concept of ideological and political education, methods, measures more suited to the needs of social development, which led people to reflect on the nature and role of ideological and political education itself way. How to make ideological and political education under the new situation, the more targeted to achieve better effectiveness, adapt to contemporary needs of social development, driving the people to explore and establish the concept of ideological and political education with the new features of the times in practice.

Third Plenum of the Party proposed a "people-centered, comprehensive, coordinated and sustainable development concept, promote the overall economic and social development and people's" scientific concept of development, which is our party to adapt to the new century, a new stage of building a well-off the objective requirements of social scientific concept of development proposed. Not only for the scientific development concept put forward demands comprehensive social development, but also for the comprehensive development of the proposed new requirements. "People-oriented" for the new era, ideological and political work under the new situation pointing out the direction. CENTRAL sixteenth spirit of the document "on further strengthening and improving ideological and political education," pointed out: "adhere to the combination of education and management and into the ideological and political education among school management, the establishment of long-term working mechanism." Insist on education and management, and "people-oriented", strengthen and improve ideological and political education, ideological and political education to enhance the relevance, effectiveness and attractiveness of appeal, and train tens of thousands have noble ideological quality and good moral cultivation, able to master the modernization needed knowledge and solid skills talents, our culture is the essential requirement of socialist builders and successors of modernization, it is related to the party and the country's fate and future of the Chinese nation's great rejuvenation It has very important significance.

Third Plenum of the Party for the first time explicitly put forward the people-oriented, comprehensive, coordinated and sustainable development concept. Scientific concept of development not only for the social set forth requirements for all-round development, but also for the comprehensive development of requests, the scientific development concept is the guiding ideology of China's economic and social development, as well as the guiding ideology of ideological and political education, "people-oriented" for the new period, ideological and political work under the new situation pointing out the direction.

The scientific development concept to guide the ideological and political education, must adhere to the people-oriented, and only adhere to the people-oriented, starting from humanity, respect for human needs, ideological and political education is scientific and effective. Essence of scientific concept of development is people-oriented, people-oriented basic meaning can be summarized as follows: to establish the status of human subjectivity; respect for people; affirm the value and significance. Thus, in the ideological and political education must be student-centered, students are the fundamental ideological and political education. 
College Students take training to become full and harmonious development to meet the requirements of social development of socialist builders and successors, and attention must strengthen ideological and political education. Ideological and political education in order to truly promote the harmonious development of overall quality of college students must adhere to the people-oriented, take full account of the psychological characteristics and behavior characteristics of college students, to carry out this work in accordance with the actual situation of university students. The contents of ideological and political education must reflect the basic spirit of the scientific concept of development, ideological and political education methods must conform to the scientific development concept. In the ideological and political education management in the past, simply by infusion or institutional constraints and methods have been contrary to the scientific concept of development, is not conducive to the growth and success of college students, and only adhere to the people-oriented in order to fully wake up and enhance the consciousness of college students, college students mobilize learning enthusiasm and initiative, so that students consciously take the initiative to self-understanding, seek truth and perfect personality, to establish a correct outlook on life and values, and promote all-round progress and harmonious development of the overall quality of students. Ideological and political education refers to colleges and universities based on the party's education policy, purposeful, planned, organized for college students world outlook and methodology of education and exert a certain psychological impact, so that students have a good ideological and political awareness, moral and psychological qualities , ideological and political education is to train college students and reflect the objective world of ideas and the ideological and political education of cognitive ability. Subject and object are the ideological and political education, with scientific theory to arm people, the human mind to solve problems and political stance, people from starting to construct a basic system in the "people" on the basis of education project, through training and improving the ideological and moral quality of social services, human development services. This is an important ideological and political education outside the law. Ideological and political education aimed at a large number of problems with the universality and immediacy of political issues and people's awareness generated in the mouth everyday life value judgments awareness education, moral formation of people meet the requirements of social development, thus pushing society forward development.

\section{Ideological and political education management humane content}

Marxist theory holds that, in the real world people have many needs, and in a variety of needs, the most basic needs is essential for the survival of mankind to clothing, food, shelter, and other things. In the "German Ideology," a book clearly states: "We should first determine the first premise of all human existence is the first premise of all history, the premise is that people in order to be able to 'make history', must be able to life. However, in order to live first need clothing, food, shelter, and other things. the first historical act is thus the production to meet these needs, the production of material life itself. it's also people just to be able to live every port must each a historical activities should be carried out, that is a basic condition "of all history.

Marx and Engels argued that human needs include the need to survive and enjoy the needs and development needs, that is, material needs, social and spiritual needs three levels. People need to recognize is the starting point of all human activity and practice, but also constitute the ideological and political education management Students humane content. They need their specific identity and social status are closely related to college students, their needs not only has the general characteristics of ordinary young people, but also has its own cultural level features. Ideological and political education management of human nature must be respected and college students, to meet the material needs of college students, social and spiritual needs, and to enhance the development of college students' needs, the only way to improve the ideological and political education management of university performance, promote college students overall development.

Marx and Engels from diverse and varied social phenomena discovered the law of development of human history, revealing the complex ideology concealed by a simple fact: people must eat, drink, 
have shelter and clothing, before it can pursue politics, science, culture, art, religion and other activities, can be seen to meet the subsistence of human social existence and development of material conditions. But Marx, human nature is no longer a need to purely natural needs, but "with a certain level of culture on historical changes occur naturally need according to Maslow's hierarchy of needs, from low to high composition a requirement hierarchy: survival needs, security needs, a home needs, esteem needs and the needs of self-realization is the most basic survival needs of a person's basic needs-material needs of contemporary college students born in the beginning of reform and opening up of China, the establishment of a socialist market economic social environment to grow up, most of them are only one child, and is in large enrollment at colleges and universities and the full implementation of quality education background, therefore, the need of contemporary college students must have its own characteristics.

\section{Summary}

Marxism holds that human society is not only a natural historical process, is the result of conscious human activity, social development is the objective law and subjective initiative dialectical unity process. Party's Third Plenum proposed a "people-centered, comprehensive, coordinated and sustainable development concept, promote the overall economic and social development and people's" scientific concept of development, people-oriented is the core and essence of scientific development, the people round comprehensive development and social progress as its starting point and goal, both on the subject of Marxist historical inheritance and insisted that it is important for the development of the theory of scientific socialism. Ideological and political education and management of students in the educational, guide, inspire people, to spur people should also respect students' subject, give full play to the inherent potential college students, to stimulate self-awareness of college students, the students themselves will vanish within the Education Management select, promote the comprehensive development of students.

\section{References}

[1] Zhangshao Rong student education management theory is based on humane Discussion of Higher, 2006,10: 129.

[2] Fang Hung Follow the spiritual needs of ideological and political education innovation Hubei Social Sciences, 2009,02: 181-183.

[3] Meng Shou on people-oriented management model of the University Student Education Forum, 2004, 02: 107.

[4] Chen Zongsheng college students need and the moral Contemporary Education Forum, 2005, 01:. 78-79.

[5] Yu karma Shikai Bin ideological and political education of humanity to explore Higher, 2009, [1] 01:. 100.

[6] Guo decided to Ideological and Political Education of Marxist Theory of Human Nature Exploration, 2004, 02: 100, 102.

[7] Li humane ideological and political education theory when meeting monthly, 2007, 08: 183.

[8] Li humane management of university students and vocational education as proposed, 2006, 30: 27. 